\title{
EVALUATION OF CLIMATE CHANGE IMPACTS ON HYDROLOGICAL PROCESSES IN THE YANGTZE RIVER DELTA REGION, CHINA
}

\author{
LIU, L. ${ }^{*}-$ LI, R. - WANG, Y. Z. \\ College of Water Resources and Civil Engineering, China Agricultural University \\ Beijing 100083, China \\ (phone: +86-10-62736533; fax: +86-10-62737796) \\ *Corresponding author \\ e-mail: liuliu@cau.edu.cn \\ (Received $28^{\text {th }}$ Oct 2016; accepted $28^{\text {th }}$ Feb 2017)
}

\begin{abstract}
Water resources in the Yangtze River Delta region have been suffering significant impacts of increasing extreme hydrological events associated with climate change. In the present work, the Taihu Basin was selected as the study area to quantify the effects of climate change on hydrological processes using an integrated modeling system, coupling the distributed hydrological model VIC (Variable Infiltration Capacity) with the regional climate model PRECIS (Providing Regional Climate for Impact Studies) generating future climate scenarios. The results indicate that the mean annual runoff under different future climate scenarios will increase, especially during flood seasons, which is consistent with the changes in precipitation and evapotranspiration for both spatial and temporal distribution, implying more frequent occurrence of extreme floods in the future. These results are significant to future water resources management and sustainable development in the Yangtze River Delta region.
\end{abstract}

Keywords: water cycle, distributed hydrological model, downscaling, flood, water resources, extreme events

\section{Introduction}

Taihu Basin, located in the Yangtze River Delta, east China, is a typical area in China with high vulnerability to natural disasters for its rapid development of economics and society. In recent years, frequent occurrence of extreme flood events in the basin has received significant attention from both local and central government in China, especially two major flood events in 1991 and 1999 with water levels that exceeded historical records and induced severe damage to local people's property and safety. Increasing extreme precipitation events associated with great spatio-temporal variation induced by climate change are expected to lead to more frequent occurrence of extreme flood events (Jiang et al., 2005; Su et al., 2006; He, 2007). For the special natural topography and great anthropogenic activities in the Taihu Basin which is a typical complex river network region mainly characterized by dense river networks, polders and hydraulic structures, it is of great importance for officials to understand and prepare to deal with the effects of climate change. Some hydrological models have been applied to investigate the impact of climate change on runoff and water resources in the Taihu Basin. The distributed hydrological model L-THIA, and the conceptual hydrological models LASCAM, STREAM and HEC-HMS (Wu et al., 2006; Zhang et al., 2006; Li et al., 2007; Wan et al., 2007) have been applied to investigate the impact of climate change on runoff and water resources in the Taihu Basin, mostly focusing on runoff simulation and the impact of LUCC on streamflow. Wang et al. (2000) analyzed the flood generating process in the Taihu Basin according to a numerical model of river network unstable flow; Gao (2002) discussed the flood 
response to land use change in the Taihu Basin and indicated that the increase of land use for construction purposes would result in serious damage. However, acceleration of the hydrological cycle induced by climate change and intensive urbanization will result in more frequent occurrence of extreme events, which could not be effectively reflected in previous studies.

In this study, VIC-3L (Variable Infiltration Capacity-Three Layer) model, the latest version of VIC, was coupled with PRECIS (Providing Regional Climate For Impacts Studies) regional climate model to assess the impact of climate change on runoff and evapotranspiration in the Taihu Basin at a spatial resolution of $5 \mathrm{~km} \times 5 \mathrm{~km}$, and the Xitiaoxi catchment located at the southwest of the basin was selected to calibrate VIC model parameters. Results of this study could be used to provide a technical support for water resources management in the Yangtze River Delta region, especially under future global climate change scenarios.

\section{Methodology}

\section{Study area description}

Taihu Basin, with an area of $36895 \mathrm{~km}^{2}$, is located on the southern side of the Yangtze River Delta region, which incorporates three provinces (Shanghai, Jiangsu and Zhejiang) currently hosting $13 \%$ of China's GDP. Due to its remarkable vulnerability to flooding and more and more significant impact of climate change, the area is now facing sever challenge for water resources management.

Area of the lakes is more than $2000 \mathrm{~km}^{2}$ in the basin, including the large Taihu Lake, from where the basin derives its name. Floodplain covered with dense river networks counts for about $67 \%$ of the total area in the basin, while others are comprised of hills or mountains. Average annual precipitation ranges from 1010 to $1400 \mathrm{~mm}$ in the basin, and most precipitation occurs between June and August in a year. Meteorological stations within or around the Taihu Basin is shown in Fig. 1.

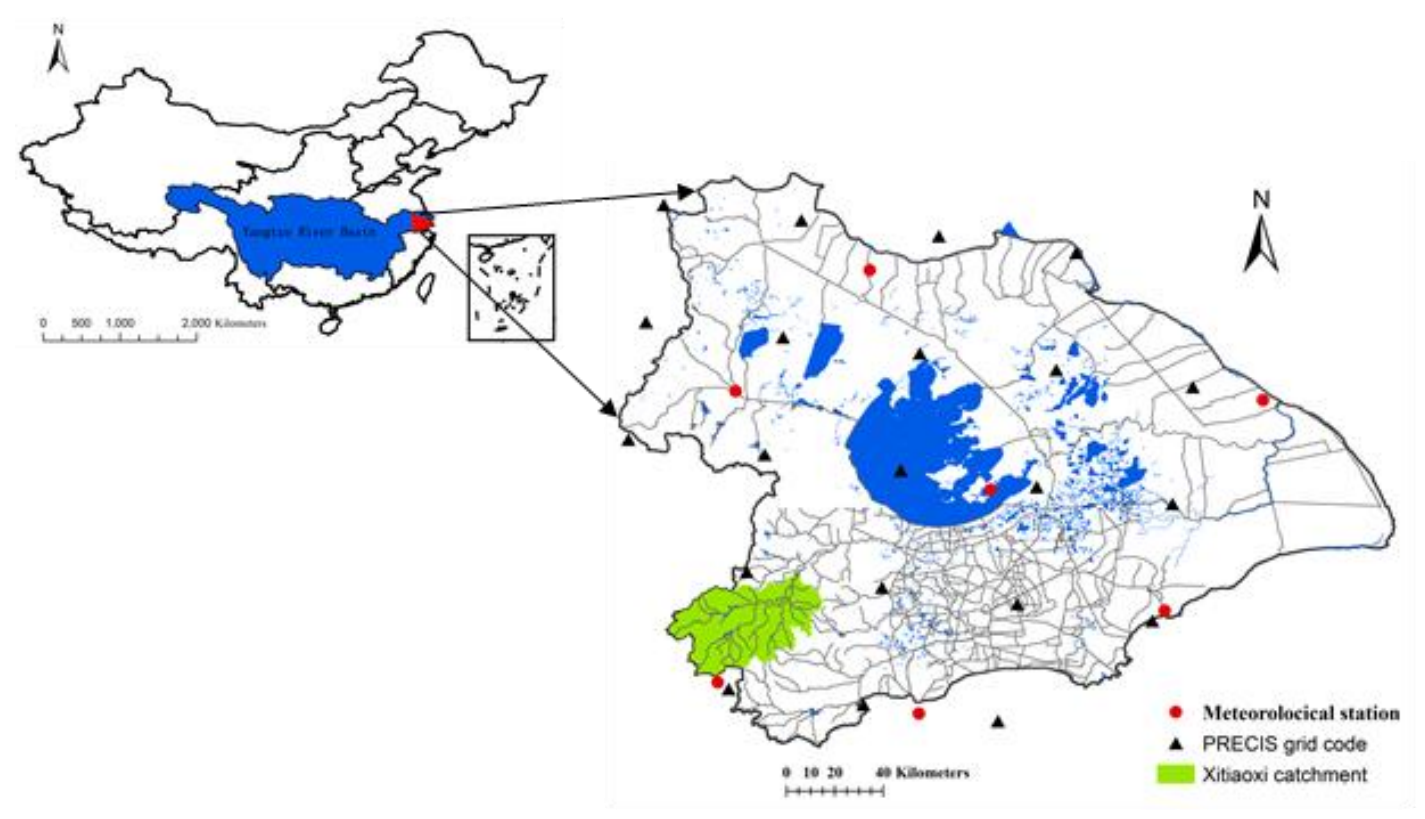

Figure 1. Location of the study area 


\section{VIC model}

The VIC macro-scale hydrological model was selected to evaluate hydrological responses to climate change in the Taihu Basin, which could be characterized as: (1) with both water balance and energy balance parameterization (Liu, 2015); (2) with two kinds of runoff generation mechanism-saturation excess runoff and infiltration excess runoff (Xie et al., 2003); (3) with the consideration of sub-grid scale soil heterogeneity (Liang and Xie, 2001); and (4) the sub-grid spatial variability of precipitation (Liang et al., 1996).

Calibration and validation of the VIC model have already been conducted by Liu and $\mathrm{Xu}$ (2015) in the Xitiaoxi catchment, which demonstrates that it is feasible to transfer parameters calibrated in the Xitiaoxi catchment to the entire basin for the impact assessment of climate change. In this study, the calibrated VIC model by Liu and Xu (2015) would be coupled with the regional climate model to evaluate climate change impacts on hydrological processes in the Taihu Basin.

\section{Regional climate model}

Details of PRECIS could be found in Jones et al. (2004). PRECIS outputs have already been successfully used to generate climate change scenarios in China for the period from 2000 to 2100, indicating spatio-temporal distributions of precipitation, maximum and minimum air temperatures in China could be simulated well by PRECIS (Xu et al., 2005; Xu and Jones, 2004). To validate the adaptability of PRECIS in the Taihu Basin, in the current study, daily precipitation, daily maximum and minimum air temperature over the Taihu Basin for baseline (Bs) during the period from 1961 to 1990 and 2030s during the period from 2021 to 2050 were simulated by running PRECIS at a $50 \mathrm{~km} \times 50 \mathrm{~km}$ resolution. A2 and B2 scenarios in terms of IPCC (Intergovernmental Panel on Climate Change) Special Report on Emissions Scenarios (SRES) were adopted. Observed data for the period 1961-1990 from the meteorological stations over the Taihu Basin were selected to validate the simulation capacity of PRECIS, the distribution of meteorological stations and PRECIS grids were shown in Fig. 1.

\section{Results}

\section{PRECIS validation}

\section{Precipitation}

In this study, precipitation intensity was graded to seven types according to meteorology observation regulation: grade $1: 0.0-0.1 \mathrm{~mm} / \mathrm{d}$, grade $2: 0.1-10.0 \mathrm{~mm} / \mathrm{d}$, grade 3: $10.0-25.0 \mathrm{~mm} / \mathrm{d}$, grade $4: 25.0 \sim-50.0 \mathrm{~mm} / \mathrm{d}$, grade $5: 50.0-100.0 \mathrm{~mm} / \mathrm{d}$, grade 6: $100.0-250.0 \mathrm{~mm} / \mathrm{d}$, grade $7:>=250.0 \mathrm{~mm} / \mathrm{d}$. Frequencies and percentiles of wet day precipitation from PRECIS and gauging stations were calculated according to these grades.

Observed precipitation data for the period 1961-1990 from 9 meteorology stations over the basin were analysed to derive extreme value statistics of 10-90 day precipitation totals. Using the Pearson-III distribution curve, extreme rainfall corresponding to the 50,100, 200 and 500 year return period events were estimated for $10,30,60,90$ day duration and for each station respectively. Results were shown in Table 1. 
Table 1. Extreme precipitation for each return period and each duration (based on observation of 1961-1990, Unit: $\mathrm{mm}$ )

\begin{tabular}{|c|c|c|c|c|c|c|}
\hline \multirow{2}{*}{ station } & \multirow{2}{*}{ duration } & \multicolumn{5}{|c|}{ long return period } \\
\hline & & $1000 a$ & $500 a$ & $200 a$ & $100 \mathbf{a}$ & $50 a$ \\
\hline \multirow{4}{*}{$\begin{array}{c}58238 \\
\text { Nanjing }\end{array}$} & $10 \mathrm{~d}$ & 593.51 & 552.15 & 496.71 & 454.02 & 410.62 \\
\hline & $30 \mathrm{~d}$ & 754.78 & 713.53 & 657.19 & 614.32 & 566.86 \\
\hline & $60 d$ & 950.36 & 905.12 & 842.93 & 793.78 & 742.15 \\
\hline & $90 \mathrm{~d}$ & 1115.76 & 1066.72 & 999.23 & 945.63 & 889.08 \\
\hline \multirow{4}{*}{$\begin{array}{c}58343 \\
\text { Changzhou }\end{array}$} & $10 \mathrm{~d}$ & 455.83 & 430.72 & 396.51 & 369.72 & 341.99 \\
\hline & $30 \mathrm{~d}$ & 638.04 & 607.67 & 565.92 & 532.92 & 498.26 \\
\hline & $60 d$ & 848.28 & 809.96 & 757.24 & 715.43 & 671.36 \\
\hline & $90 \mathrm{~d}$ & 1054.99 & 1011.23 & 950.99 & 903.04 & 852.40 \\
\hline \multirow{4}{*}{$\begin{array}{l}58345 \\
\text { Liyang }\end{array}$} & $10 \mathrm{~d}$ & 503.45 & 472.74 & 431.23 & 399.03 & 365.89 \\
\hline & $30 \mathrm{~d}$ & 658.47 & 625.82 & 581.15 & 546.77 & 509.35 \\
\hline & $60 d$ & 900.25 & 858.48 & 801.04 & 755.55 & 707.70 \\
\hline & $90 \mathrm{~d}$ & 1103.07 & 1057.31 & 994.33 & 944.20 & 891.24 \\
\hline \multirow{4}{*}{$\begin{array}{l}58358 \\
\text { Wuxiandongshan }\end{array}$} & $10 \mathrm{~d}$ & 401.09 & 378.45 & 347.85 & 324.05 & 299.49 \\
\hline & $30 \mathrm{~d}$ & 619.49 & 588.30 & 545.69 & 513.36 & 477.36 \\
\hline & $60 d$ & 805.79 & 771.36 & 723.98 & 686.30 & 646.52 \\
\hline & $90 \mathrm{~d}$ & 990.79 & 950.69 & 895.45 & 851.45 & 804.97 \\
\hline \multirow{4}{*}{$\begin{array}{l}58367 \\
\text { Longhua }\end{array}$} & $10 \mathrm{~d}$ & 409.36 & 388.91 & 360.91 & 338.79 & 315.58 \\
\hline & $30 \mathrm{~d}$ & 639.07 & 607.39 & 564.03 & 530.67 & 494.35 \\
\hline & $60 d$ & 809.35 & 774.77 & 727.17 & 689.33 & 649.38 \\
\hline & $90 \mathrm{~d}$ & 1053.73 & 1008.71 & 946.74 & 897.46 & 845.45 \\
\hline \multirow{4}{*}{$\begin{array}{c}58436 \\
\text { Ningguo }\end{array}$} & $10 \mathrm{~d}$ & 666.65 & 614.49 & 545.09 & 492.25 & 439.09 \\
\hline & $30 \mathrm{~d}$ & 933.23 & 870.60 & 786.77 & 722.32 & 656.90 \\
\hline & $60 d$ & 1127.79 & 1064.94 & 979.99 & 914.12 & 846.32 \\
\hline & $90 \mathrm{~d}$ & 1591.68 & 1495.22 & 1365.52 & 1265.48 & 1163.54 \\
\hline \multirow{4}{*}{$\begin{array}{c}58445 \\
\text { Tianmushan }\end{array}$} & $10 \mathrm{~d}$ & 494.02 & 470.02 & 437.16 & 411.20 & 383.97 \\
\hline & $30 \mathrm{~d}$ & 756.64 & 726.28 & 684.39 & 650.98 & 615.66 \\
\hline & $60 \mathrm{~d}$ & 1092.17 & 1051.23 & 994.70 & 949.53 & 901.59 \\
\hline & $90 \mathrm{~d}$ & 1364.65 & 1317.41 & 1251.74 & 1199.15 & 1143.40 \\
\hline \multirow{4}{*}{$\begin{array}{c}58457 \\
\text { Hangzhou }\end{array}$} & $10 \mathrm{~d}$ & 440.99 & 418.55 & 387.84 & 364.01 & 338.45 \\
\hline & $30 \mathrm{~d}$ & 684.16 & 653.25 & 610.73 & 577.00 & 541.46 \\
\hline & $60 d$ & 863.05 & 829.60 & 783.25 & 746.39 & 707.29 \\
\hline & $90 \mathrm{~d}$ & 1107.78 & 1064.31 & 1004.51 & 957.14 & 907.28 \\
\hline \multirow{4}{*}{$\begin{array}{l}58464 \\
\text { Pinghu }\end{array}$} & $10 \mathrm{~d}$ & 666.68 & 612.48 & 540.65 & 486.03 & 431.16 \\
\hline & $30 \mathrm{~d}$ & 681.61 & 646.90 & 599.41 & 561.89 & 522.55 \\
\hline & $60 d$ & 809.91 & 775.31 & 727.68 & 689.80 & 649.82 \\
\hline & $90 \mathrm{~d}$ & 957.17 & 919.13 & 866.77 & 825.21 & 781.37 \\
\hline
\end{tabular}

Based on the daily gridded data from PRECIS and observed data from nine gauging stations (as shown in Table 1), seasonal and annual mean precipitation for the Taihu Basin were obtained by spatial interpolation, from which frequency-intensity curves of 
precipitation were drawn. As shown in Fig. 2, most part of frequency-intensity curves of PRECIS and observation fit well, implying a satisfied simulation capacity of PRECIS in the Taihu Basin. However, frequencies of grade $2(0.1-10.0 \mathrm{~mm})$ simulated by PRECIS are higher than those from gauging stations in all calculated time-scales, especially in summer, while frequencies of grade $4(25.0-50.0 \mathrm{~mm})$ from PRECIS are smaller than those calculated by observed data, where most difference also occurs in summer.
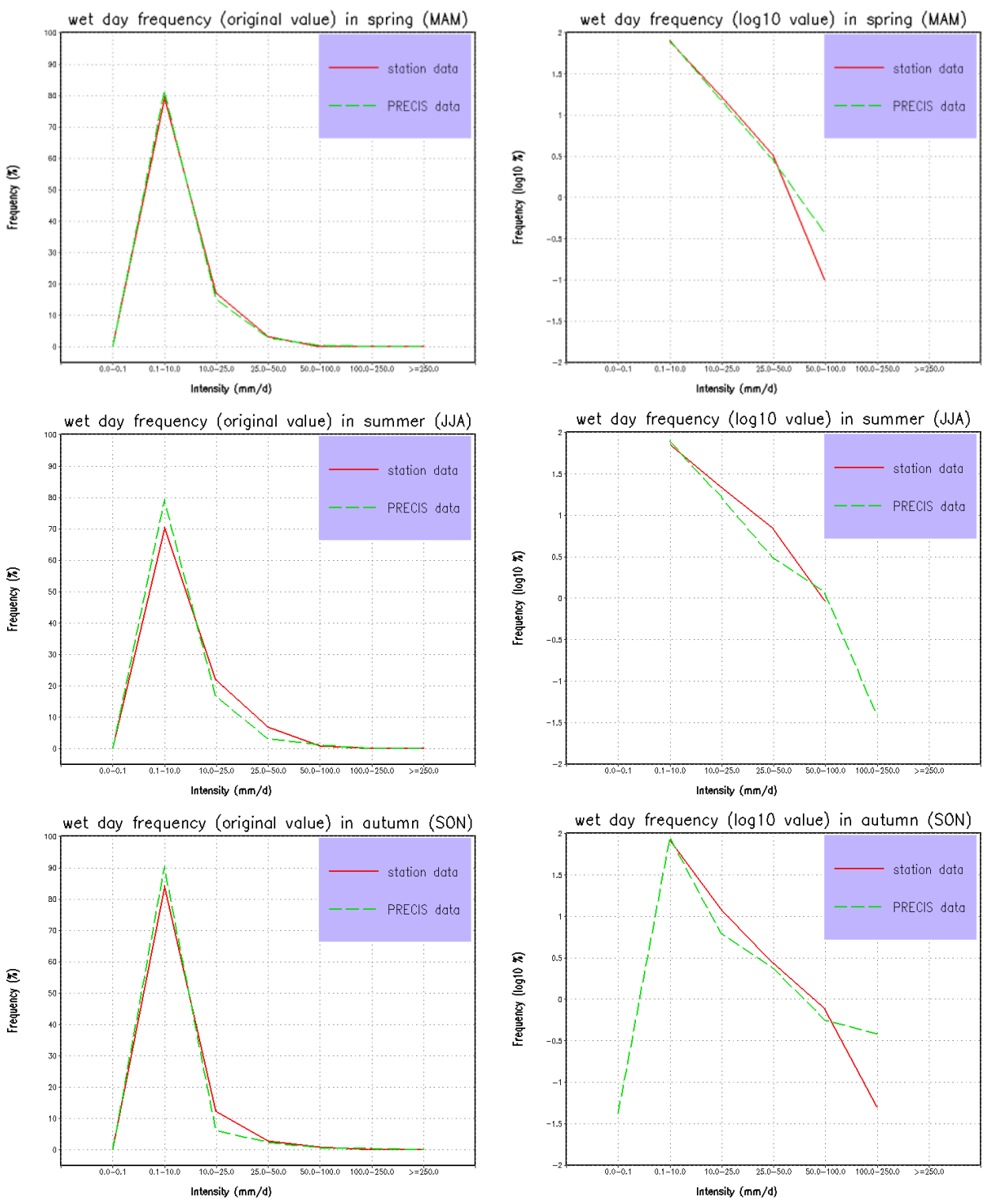

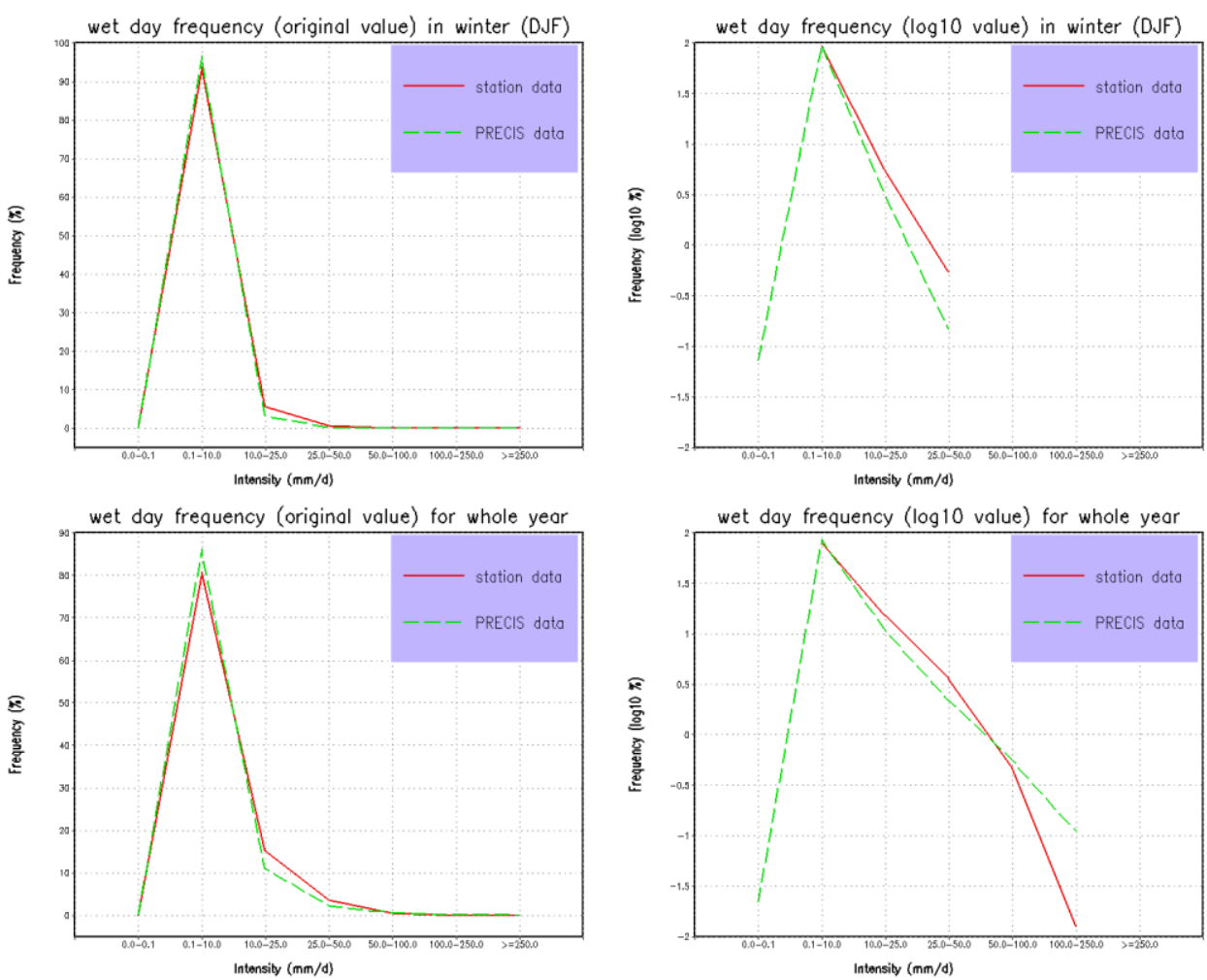

Figure 2. Frequency-intensity curve (left) and log 10 curve (right) of precipitation of region average for each season and whole year data

$X, Y$-coordinate represent intensity (unit: $\mathrm{mm} / \mathrm{d}$ ) and frequency (unit: \%) respectively

The mean annual frequency-intensity curves of wet day precipitation for nine gauging stations and the whole basin were used to assess the simulation effect of spatial patterns. For PRECIS data, the curve was drawn based on the data from the grid-box containing the corresponding station. As shown in Fig. 3, gridded simulations from PRECIS fit quite well with observations from nine gauging stations, while there is a slight difference after interpolating to the whole basin.
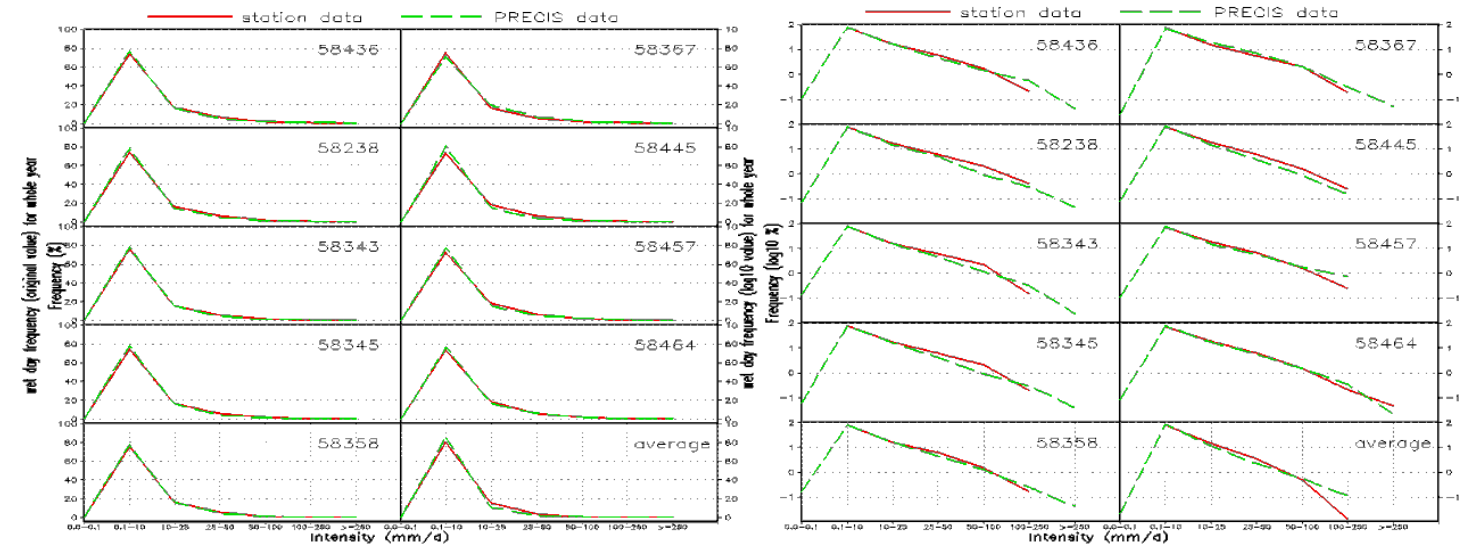

Figure 3. Frequency-intensity curve (left) and log10 curve (right) of precipitation for each station and region average (bottom right in each map) for whole year data $X, Y$-coordinate represent intensity (unit: $\mathrm{mm} / \mathrm{d}$ ) and frequency (unit: \%) respectively 
Figs. 4 and 5 are the wet day precipitation percentile curves of PRECIS data and observed data. Both the original value and $\log 10$ value are showed for details of extreme value (frequency or percentile). Because some value (frequency or percentile) is zero, the corresponding $\log 10$ value is undefined. Apparently, distributions of percentiles of PRECIS data are quite close to those of observed data, which are consistent with results obtained from frequency-intensity curves aboved.
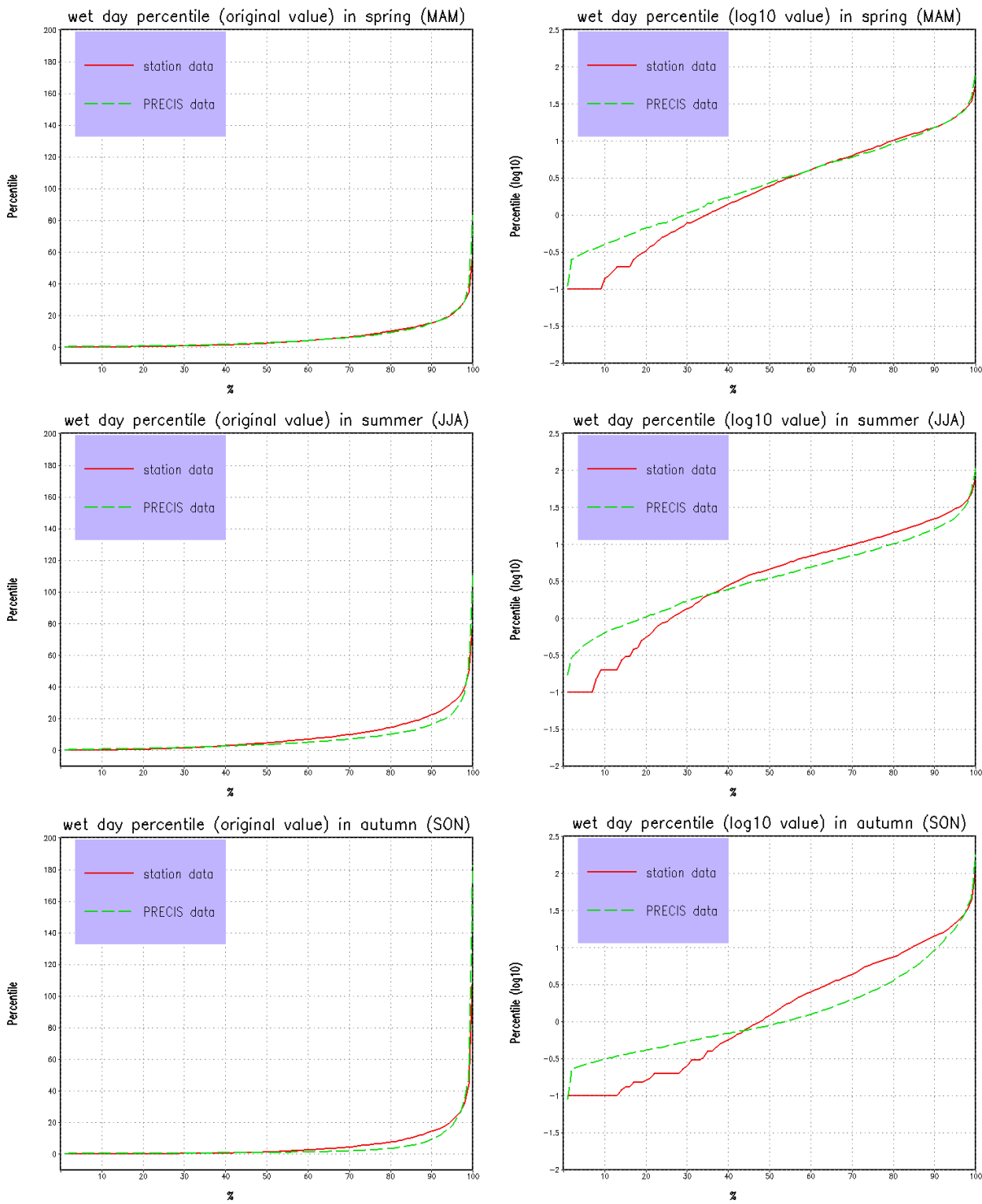

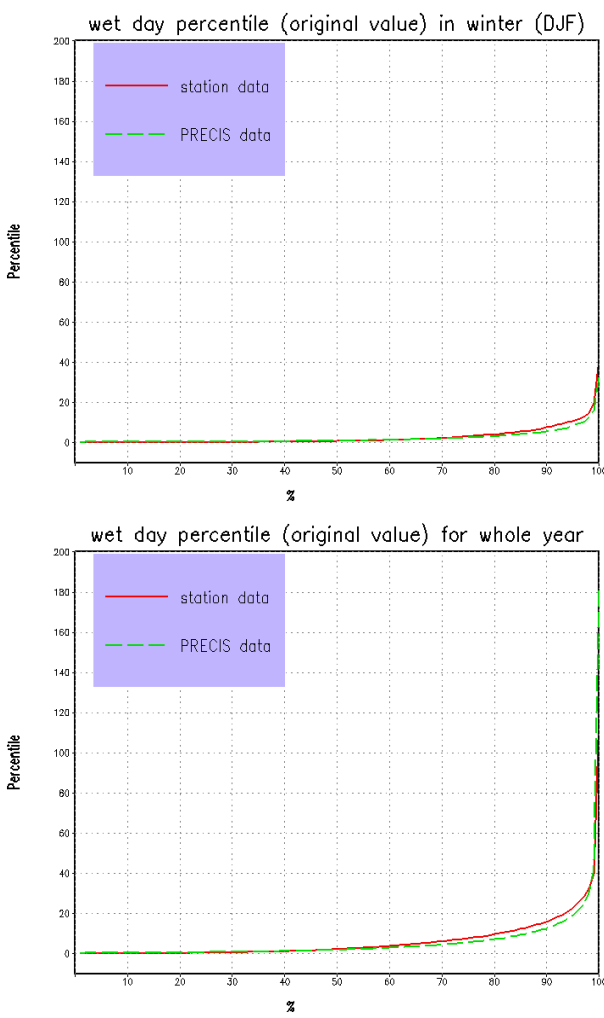
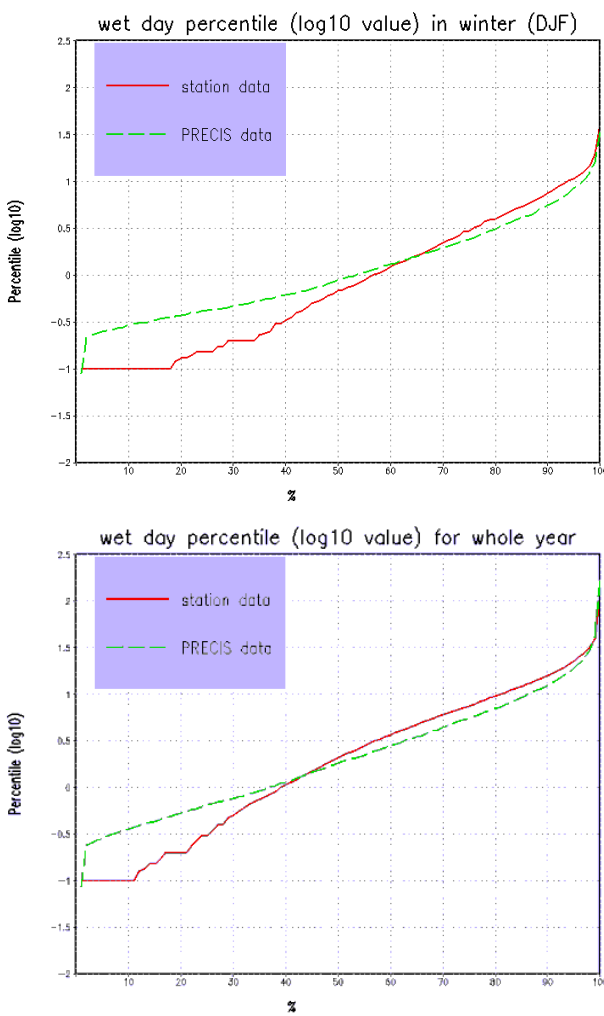

Figure 4. Percentiles curve (left) and log10 curve (right) of precipitation of region average for each season and whole year data

$X, Y$-coordinate represent frequency (unit: \%) and percentiles (unit: $\mathrm{mm} / \mathrm{d}$ ) respectively
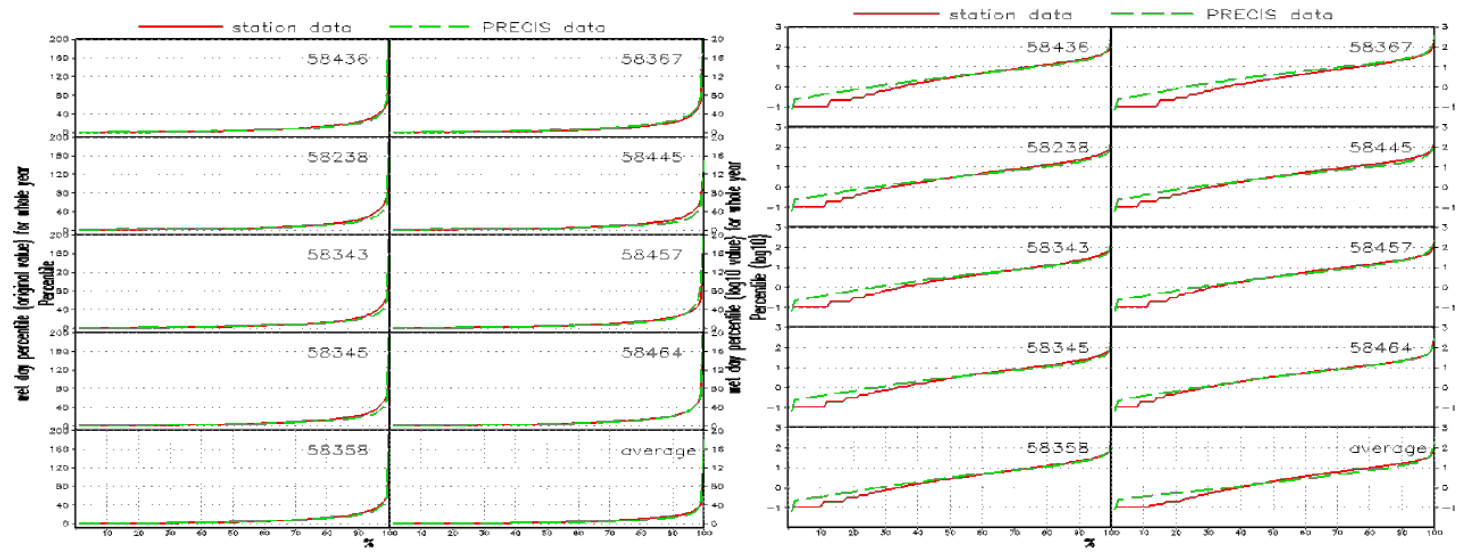

Figure 5. Percentiles curve (left) and log10 curve (right) of precipitation for each station and region average (bottom right in each map) for whole year data

$X, Y$-coordinate represent frequency (unit: \%) and percentiles (unit: $\mathrm{mm} / \mathrm{d}$ ) respectively

\section{Maximum/minimum temperature}

In order to drive VIC model, daily maximum and minimum temperature data are also needed. Similar with precipitation validation, frequency-intensity curves were used to assess the simulation capacity of PREICS. Time series of temperature from PRECIS 
and gauging stations were all corrected to sea level to eliminate bias induced by different elevations from PRECIS grids and gauging stations. As shown in Figs. 6 and 7, outputs of PRECIS fit well with observations. However, for the maximum temperature, the frequency of extreme high value of PRECIS is higher than that of observations, and for the minimum temperature, the frequency of extreme low/high temperature of PRECIS is also higher than that of observations from most of stations.
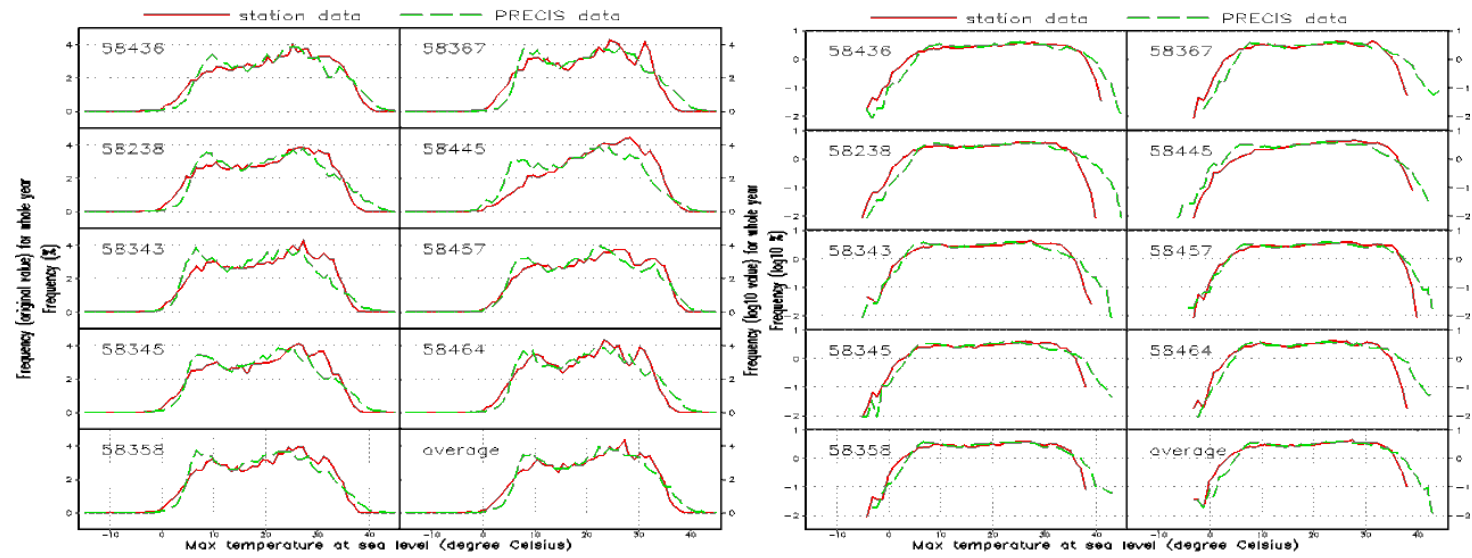

Figure 6. Frequency curve (left) and log 10 curve (right) of observation and PRECIS maximum temperature of 1961-1990 for each station and region average (bottom right) $X, Y$-coordinate represent temperature (unit: ${ }^{\circ} \mathrm{C}$ ) and frequency (unit: \%) respectively
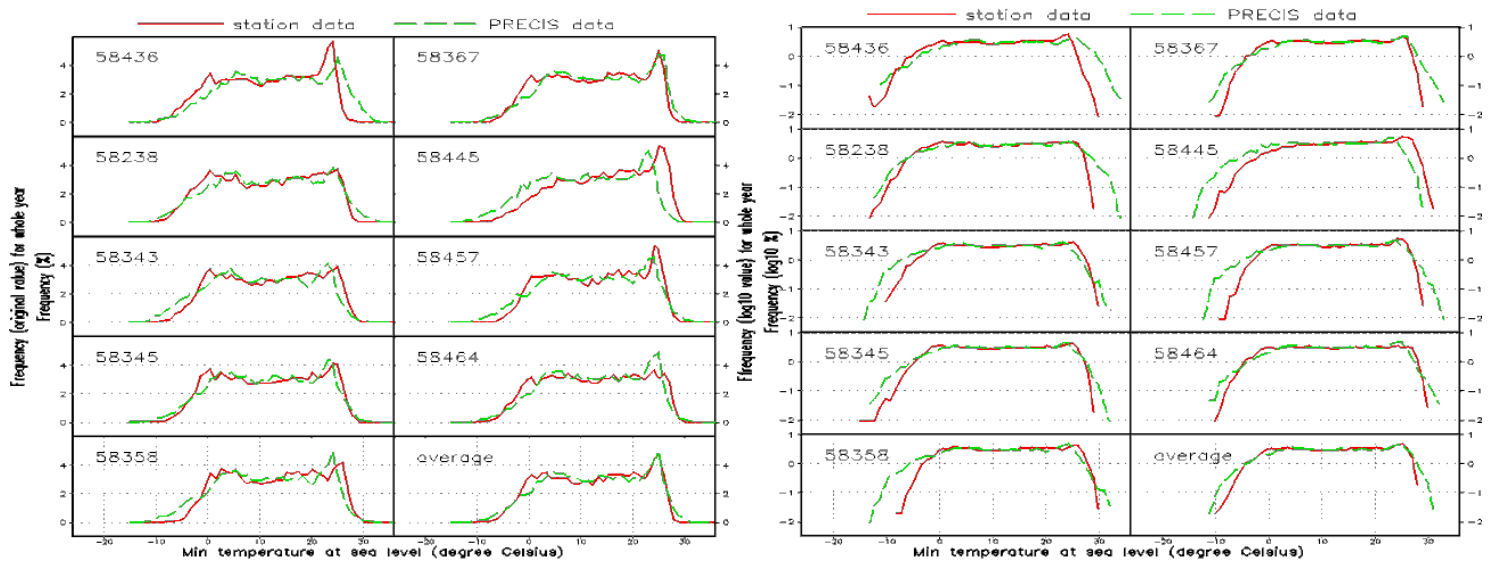

Figure 7. Frequency curve (left) and log10 curve (right) of observation and PRECIS minmum temperature of 1961-1990 for each station and region average (bottom right) $X, Y$-coordinate represent temperature (unit: ${ }^{\circ} \mathrm{C}$ ) and frequency (unit: \%) respectively

\section{Impact assessment}

The calibrated VIC model (Liu and $\mathrm{Xu}, 2015$ ) was driven using the PRECIS outputs of daily precipitation, daily maximum and minimum temperatures for the baseline and 2030s to generate runoff and evapotranspiration in 1452 grids that covering the entire Taihu Basin at a resolution of $5 \mathrm{~km} \times 5 \mathrm{~km}$.

As shown in Table 2, mean annual precipitation and runoff in the Taihu Basin under A2 and B2 scenarios during 2021-2050 compared with that during 1961-1990 exhibit increasing trends, ranging from $5.97 \%-3.54 \%$ and $10.63 \%-12.13 \%$, respectively. While 
mean annual evapotranspiration tends to decrease by $-1.96 \%$ under B2 scenario and increase only by $2.73 \%$, which could be ignored compared to the significant increasing of temperature in the Taihu Basin, seemingly opposite of the general expectation which is global warming will lead to an increase in evapotranspiration. Similar changing characteristics in the Yangtze River Basin have already been found (Wang et al., 2007; $\mathrm{Xu}$ et al., 2006a; 2006b), implying both potential evapotranspiration and crop reference evapotranspiration have declined over recent decades in a globally warming climate. By comparing 148 regional studies on trends in evapotranspiration over the world, McVicar et al. (2012) advocates that in addition to considering air temperature trends, trends in wind speed, atmospheric humidity and the radiative balance must also be considered to fully understand trends of evapotranspiration in a changing climate. More sophisticated exploitation on spatio-temporal characteristics of evapotranspiration in the Taihu Basin should be studied in the future.

Table 2. Mean annual statistics under different scenarios

\begin{tabular}{cccccc}
\hline Variables & $\begin{array}{c}\text { Baseline } \\
\mathbf{m m}\end{array}$ & $\begin{array}{c}\mathbf{A 2} \\
\mathbf{m m}\end{array}$ & $\begin{array}{c}\text { B2 } \\
\mathbf{m m}\end{array}$ & $\begin{array}{c}\text { A2-Change } \\
\text { \% }\end{array}$ & $\begin{array}{c}\text { B2-Change } \\
\text { \% }\end{array}$ \\
\hline Precipitation & 1186.38 & 1257.15 & 1228.42 & 5.97 & 3.54 \\
Runoff & 444.52 & 491.75 & 498.45 & 10.63 & 12.13 \\
Evapotranspiration & 731.82 & 751.80 & 717.47 & 2.73 & -1.96 \\
\hline
\end{tabular}

Due to suffering frequent floods which cause huge losses of wealth and life, mostly occurring during the plume rain season from May to September, one of the most concerned problems in the Taihu Basin is flood management. Therefore, in this study, attention is mainly focused on the spatio-temporal characteristics of hydrological processes during the plume rain season under future climate change scenarios. The nonparametric Mann-Kendall test proposed by Mann (1945) and improved by Kendall (1975) was employed to test trends of precipitation, runoff and evapotranspiration owing to its capability of handling non-normality and seasonality (Gan, 1998). The Kendall slope, which is an unbiased estimator of trend magnitude, was adopted to estimate the magnitude of the trend. Based on the precipitation, runoff and evapotranspiration in each grid during May to September from 2021 to 2050, which were extracted from outputs simulated by coupled VIC model and PRECIS, the Kendall slope in each grid was calculated at the confidence level of $95 \%$ and shown in Figs. 8 and 9.

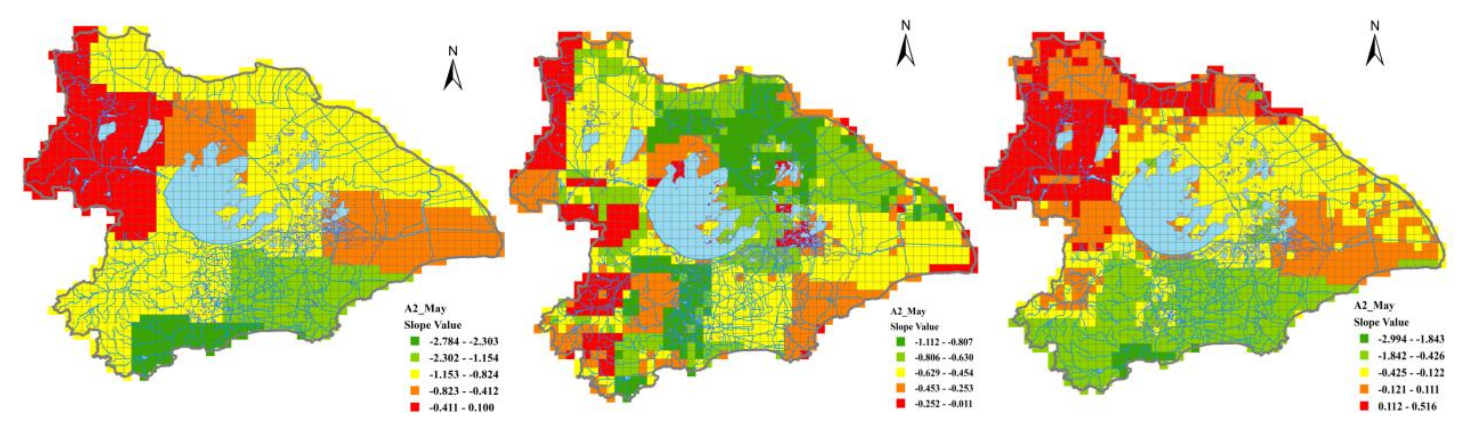



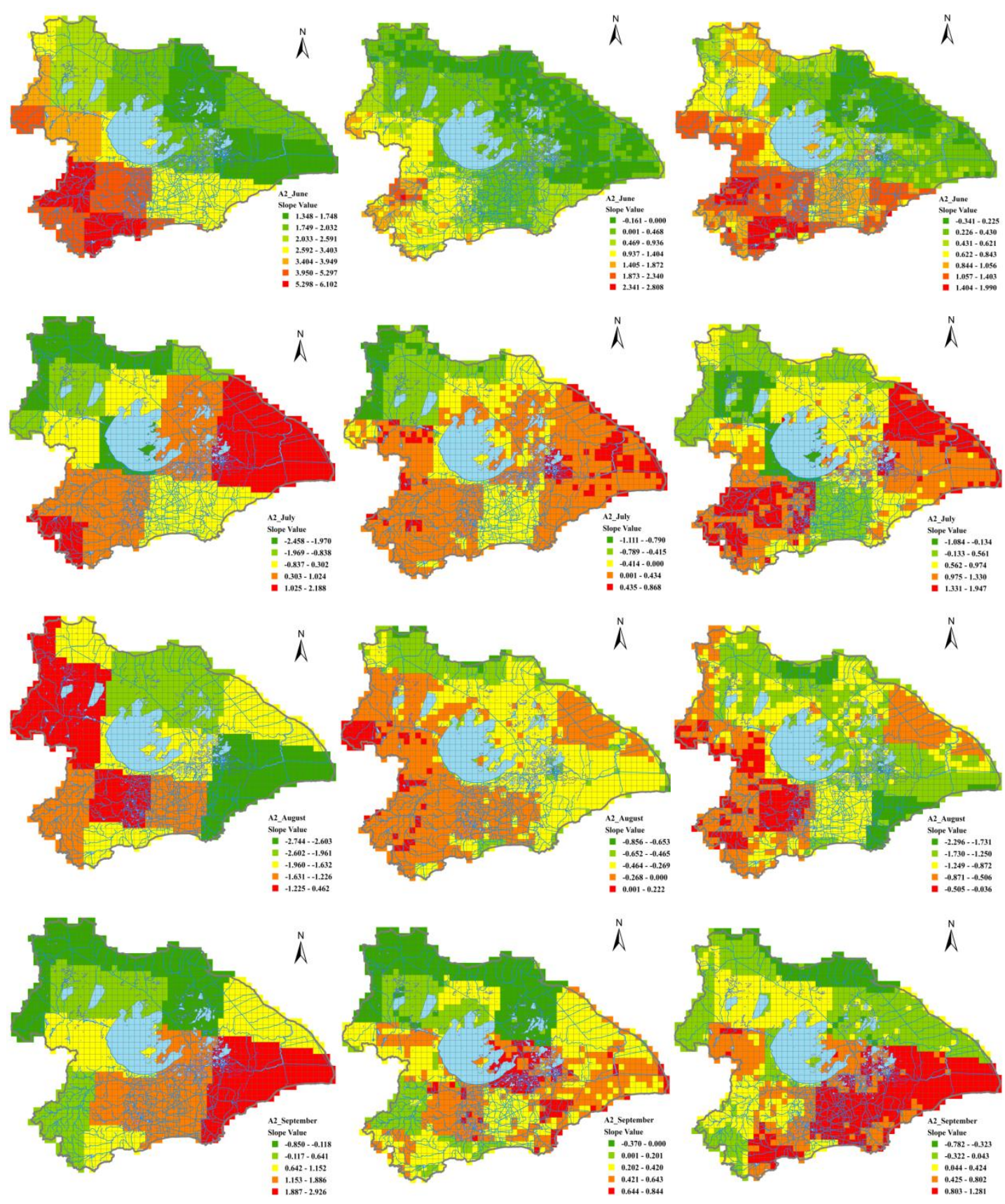

Figure 8. Kendall slopes of monthly precipitation, runoff depth and evapotranspiration during plume rain season from 2021-2050 under A2 scenario (Left column is precipitation, middle column is runoff depth, and right column is evapotranspiration)
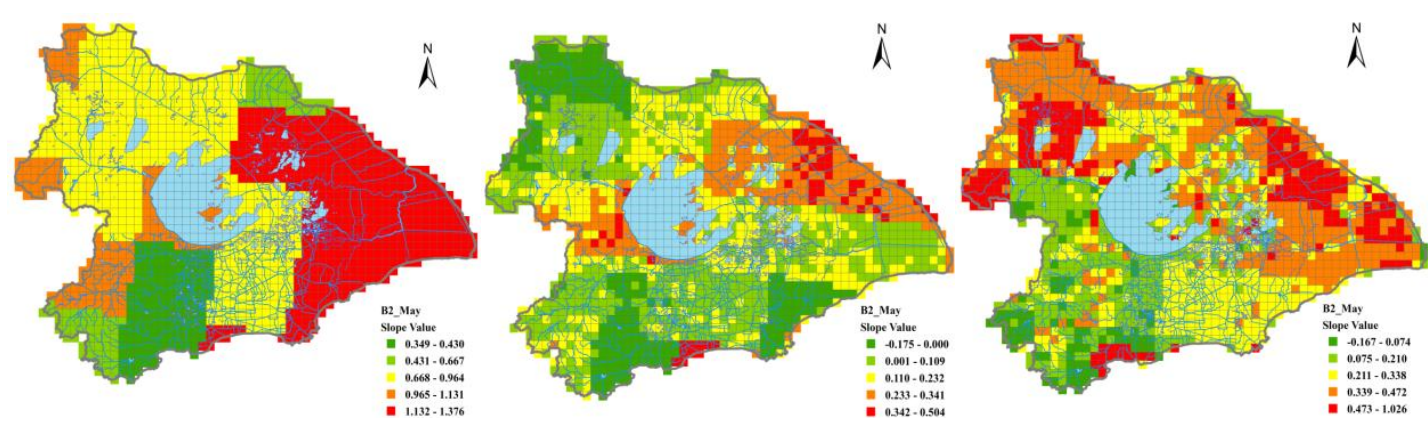

APPLIED ECOLOGY AND ENVIRONMENTAL RESEARCH 15(3): 1025-1040. http://www.aloki.hu • ISSN 15891623 (Print) • ISSN 17850037 (Online)

DOI: http://dx.doi.org/10.15666/aeer/1503_10251040

(c) 2017, ALÖKI Kft., Budapest, Hungary 


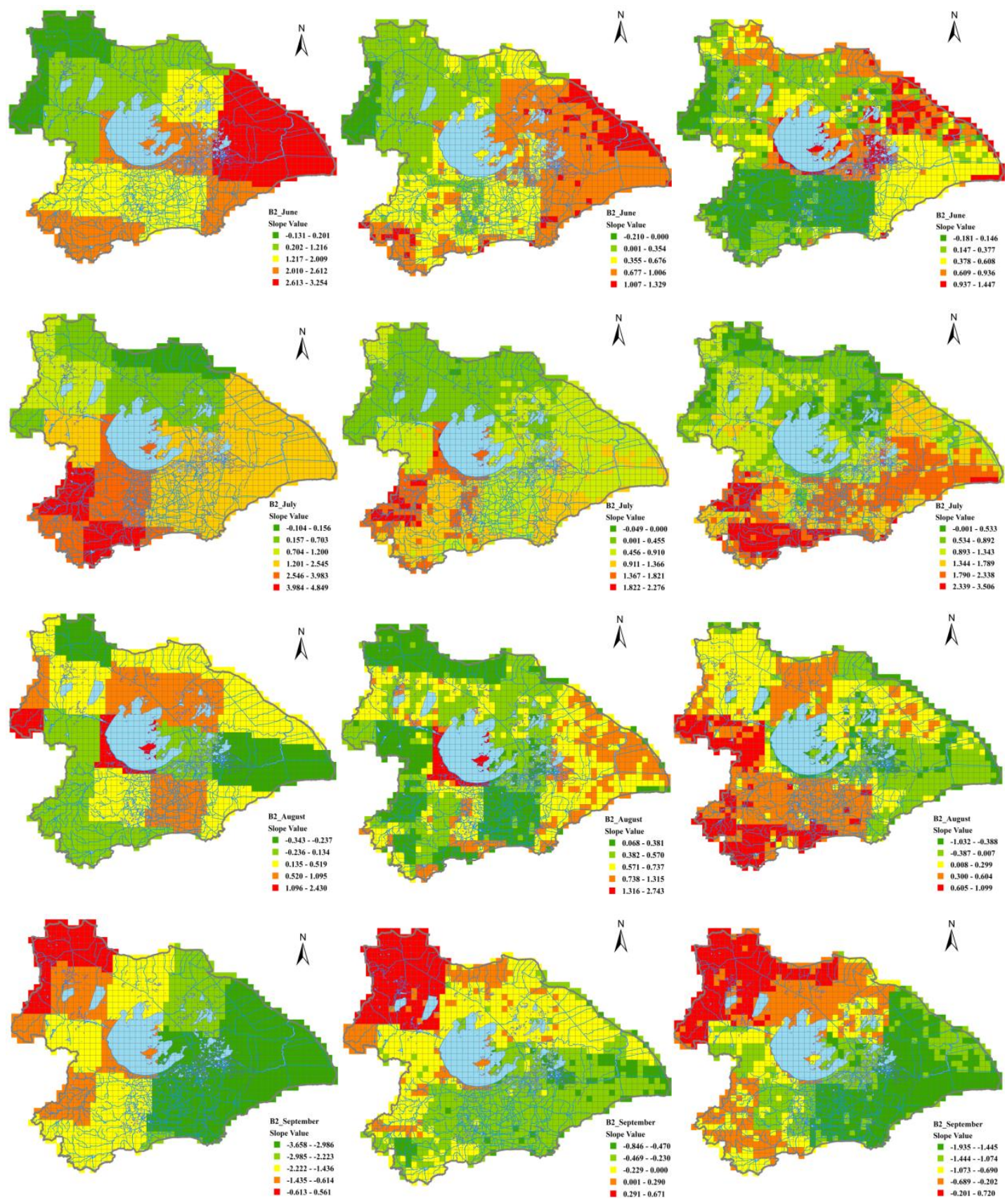

Figure 9. Kendall slopes of monthly precipitation, runoff depth and evapotranspiration during flood season from 2021-2050 under B2 scenario (Left column is precipitation, middle column is runoff depth, and right column is evapotranspiration)

As Fig. 8 shows, runoff depth in May under A2 scenario during 2021-2050 exhibits a decreasing trend in the whole basin, with Kendall slopes ranging from -11.12 - -0.11 $\mathrm{mm} /(10$ years $)$, and higher decreasing magnitudes occur in north compared with that in south. Precipitation in May shows a similar decreasing trend with larger Kendall slopes compared with runoff depth in most parts of the Taihu Basin, while a slight increasing trend was detected in the northeastern part with a Kendall slope of $1.00 \mathrm{~mm} /(10$ years $)$. The reason increasing of precipitation accompanied with decreasing of runoff in 
northeast could be explained by increasing of evapotranspiration as shown in the right column of Fig. 8, which is consistent with results obtained by Bao and Feng (2016), Guan et al. (2014), and Zhang et al. (2014). Furthermore, in other parts of the Taihu Basin, decreasing magnitude of runoff is less than that of precipitation in May, for the reason that there is a decreasing trend of evapotranspiration in the corresponding area, consistent with water balance principle. Similar hydrological responses in both spatial distribution and changing magnitude were found in August.

As to changing patterns in June, there are decreasing trends of runoff depth in the northern part of the basin and the Shanghai surrounding area with relative small magnitudes ranging from -1.61-0.00 $\mathrm{mm} /$ (10 years), which are opposite of the increasing of precipitation due to increasing of evapotranspiration. Other parts of the basin exhibit increasing trends, especially in southeastern mountain region with Kendall slopes all over $9 \mathrm{~mm} /(10$ years $)$, similar consistent changing features of precipitation and evapotranspiration could also be found.

Compared with Kendall slopes of runoff depth in June, areas with decreasing trends shift from northeast to northwest and south in July, with larger 10-year decreasing rates of -11.11-0.00 $\mathrm{mm}$, while the zone with increasing trends expands to east with relative smaller magnitudes ranging from $0.01-8.68 \mathrm{~mm} /(10$ years $)$.

In September, precipitation, runoff and evapotranspiration all exhibit increasing trends in most parts of the basin except the northern part. Although there is a significant increasing of precipitation in the eastern part with the highest 10 -year rate of $29.26 \mathrm{~mm}$, there is no corresponding highest increasing of runoff depth attributing to remarkable increasing of evapotranspiration in the east, implying that only considering precipitation traditionally recognized as the key factor of flood in the Taihu Basin is not sufficient to identify and quantify flood disasters. Similar results were also obtained by Lai et al. (2013), Lu et al. (2014), Ping et al. (2014).

Kendall slopes of precipitation, runoff and evapotranspiration during 2021-2050 under B2 scenario are shown in Fig. 9. Compared with decreasing trends of runoff over the whole basin in May under A2 scenario, runoff under B2 scenario in May shows an increasing trend in most parts, with Kendall slopes of $0.01-5.04 \mathrm{~mm} /(10$ years $)$, while a slight decreasing trend is situated in part of Zhexi and Huxi district with the 10-year decreasing rate of $-1.75-0.00 \mathrm{~mm}$. As to June, decreasing trend was only detected in the western part of Huxi district while other parts of the basin exhibit increasing trends, especially in the upstream of Zhexi district and northeastern part of the Taihu Basin with Kendall slopes all over $6.77 \mathrm{~mm} /(10$ years $)$.

Different from A2 scenario, there is a significant increasing trend of runoff in July under B2 scenario over the whole basin, especially in southeastern part with Kendall slopes all over $10.00 \mathrm{~mm} /(10$ years $)$. In August, an increasing trend of runoff over the whole basin was detected under B2 scenario with 10-year rate of 0.68-2.74 mm, which is opposite of the decreasing trend under A2 scenario. Trends of runoff in September under B2 and A2 scenarios are also opposite, which are increasing under B2 scenario and decreasing under A2 scenario. Similar with results obtained under A2 scenario, precipitation and evapotranspiration keep consistency in both spatial patterns and changing magnitudes in terms of water balance principle under B2 scenario.

Although there are differences of runoff during the plume rain season from 2021 2050 under A2 and B2 scenarios, it could be confirmed that there will be an increasing trend of runoff in south while the northern part will exhibit a decreasing trend in the future. 


\section{Conclusions}

In this study, the Taihu Basin was selected as the typical area of the Yangtze River Delta region to investigate the climate change impacts on hydrological processes. The VIC model was coupled with PRECIS regional climate model to assess the impact of climate change on hydrological conditions at a spatial resolution of $5 \mathrm{~km} \times 5 \mathrm{~km}$. Outputs including daily precipitation, maximum and minimum air temperature from PRECIS under three climate scenarios, i.e. baseline climate (1961-1990), future climate (2021-2050) under A2 and B2, were adopted to drive the VIC model to simulate the changes of runoff and evapotranspiration in the Taihu Basin.

The Taihu Basin was represented by 1452 cells with a spatial resolution of $5 \mathrm{~km} \times 5$ $\mathrm{km}$ for each cell to assess the hydrological response to climate change by VIC model. VIC model parameters calibrated in the Xitiaoxi catchment was transferred to the whole basin based on the assumption that the hydrological process and its related parameters are similar in a same climate zone. The runoff simulation showed an increasing trend from 2021 to 2050 based on the scenarios obtained by PRECIS, especially in the southern part of the basin.

Precipitation, with great spatial and temporal variability, is a great dominant factor in controlling floods in the Taihu Basin. However, to identify and quantify flood disasters precisely, combined qualitative analysis on spatial patterns of precipitation, runoff and evapotranspiration are necessary. Therefore, accurate simulation of precipitation, evapotranspiration and other related hydro-meteorological factors is of great importance to conduct cross-validation for the climate change impact assessment.

Acknowledgements. This work was jointly supported by the National Natural Science Foundation of China (51509247, 91425302). Assistance from colleagues in the Taihu Basin Authority and Chinese Academy of Agricultural Sciences who kindly provided valuable data and comments from reviewers that greatly improved the quality of the paper are gratefully acknowledged as well.

\section{REFERENCES}

[1] Bao, J. W., Feng, J. M. (2016): Intercomparison of CMIP5 simulations of summer precipitation, evaporation, and water vapor transport over Yellow and Yangtze River basins. - Theoretical Applied Climatology 123: 437-452.

[2] Gan, T. Y. (1998): Hydroclimatic trends and possible climatic warming in the Canadian Prairies. -Water Resources Research 34(11): 3009-3015.

[3] Gao, J. F. (2002): Flood response to land use change in Taihu Lake Basin. - Journal of Natural Resources 17 (2): 150-156.

[4] Guan, Y. H., Zhang, X. C., Zheng, F. L., Wang, B. (2014): Trends and variability of daily temperature extremes during 1960-2012 in the Yangtze River Basin, China. - Global and Planetary Change 124: 79-94.

[5] He, L. (2007): Impacts of global temperature changes in last century on precipitation in the Yangtze River Basin. - Resources Environment and Development 4: 4-7.

[6] Jiang, T., Su, B. D., Wang, Y. J., Zhang, Q., Qin, N. X., Shi, Y. F. (2005): Trends of temperature, precipitation and runoff in the Yangtze River Basin from 1961 to 2000. Advances in Climate Change Research 1(2): 65-68.

[7] Jones, R. G., Noguer, M., Hassell, D. C., Hudson, D., Wilson, S. S., Jenkins, G. J., Mitchell, J. F. B. (2004): Generating high resolution climate change scenarios using PRECIS. - Met Office Hadley Centre: Exeter, UK.

[8] Kendall, M. G. (1975): Rank Correlation Methods. - Griffin, London, UK. 
[9] Lai, X. J., Jiang, J. H., Liang, Q. H., Huang, Q. (2013): Large-scale hydrodynamic modeling of the middle Yangtze River Basin with complex river-lake interactions. Journal of Hydrology 492: 228-243.

[10] Li, H. P., Wang, X. Q., Yange, S. S., Jin, Y. (2007): Application of Grid Based STREAM Distributed Hydrological Model-A Case Study IN Xitiaoxi Watershed of Taihu Basin. Resources and Environment in the Yangtze Basin 16(6): 715-720.

[11] Liang, X., Lettenmaier, D. P., Wood, E. F. (1996): One-dimensional statistical dynamic representation of subgrid spatial variability of precipitation in the two-layer variable infiltration capacity model. - Journal of Geophysical Research 101(D16): 21403-21422.

[12] Liang, X., Xie, Z. H. (2001): A new surface runoff parameterization with subgrid-scale soil heterogeneity for land surface models. - Advances in Water Resources 24(9-10): 1173-1193.

[13] Liu, L., Xu, Z. X. (2015): Hydrological projections based on the coupled hydrologicalhydraulic modeling in the complex river network region: a case study in the Taihu basin, China. - Journal of Water and Climate Change 6(2): 386-399.

[14] Liu, W. F., Xu, Z. X., Li, F. P., Zhang, L., Zhao, J., Yang, H. (2015): Impacts of climate change on hydrological processes in the Tibetan Plateau: A case study in the Lhasa River basin. - Stochastic Environmental Research and Risk Assessment 29(7): 1809-2822.

[15] Lu, E., Liu, S. Y., Luo, Y. L., Zhao, W., Li, H., Chen, H. X., Zeng, Y. T., Liu, P., Wang, X. M., Higgins, R. W., Halpert, M. S. (2014): The atmospheric anomalies associated with the drought over the Yangtze River basin during spring 2011. - Journal of Geophysical Research: Atmospheres 119: 5881-5894.

[16] Mann, H. B. (1945): Nonparametric tests against trend. - Econometrica 13: 245-259.

[17] McVicar, T. R., Roderick, M. L., Donohue, R. J., Li, L. T., Van Niel, T. G., Thomas, A., Grieser, J., Jhajharia, D., Himri, Y., Mahowald, N. M., Mescherskaya, A. V., Kruger, A. C., Rehman, S., Dinpashoh, Y. (2012): Global review and synthesis of trends in observed terrestrial near-surface wind speeds: Implications for evaporation. - Journal of Hydrology (416-417): 182-205.

[18] Ping, F., Tang, X. B., Gao, S. T., Luo, Z. X. (2014): A comparative study of the atmospheric circulations associated with rainy-season floods between the Yangtze and Huaihe River Basins. - Science China - Earth Sciences 57: 1464-1479.

[19] Su, B. D., Jiang, T., Ren, G. Y., Chen, Z. H. (2006): Observed trends of precipitation extremes in the Yangtze River Basin during 1960 to 2004. - Advances in Climate Change Resesarch 2(1): 9-14.

[20] Wan, R. R., Yang, G. S., Li, H. P., Yang, L. X. (2007): Simulating Flood Evens in Mesoscale Watershed: a Case Study from River Xitiaoxi Watershed in the Upper Region of Taihu Basin. - Journal of Lake Sciences 19(2): 170-176.

[21] Wang, L. C., Xie, S. P., Zhou, Y. K., Du, J. K., Pan, H. L. (2000): Submerged simulation of flooding and waterlogging in Taihu Watershed. - Acta Geographica Sinica 55 (1): 4654 ..

[22] Wang, Y., Jiang, T., Bothe, O., Fraedrich, K. (2007): Changes of pan evaporation and reference evapotranspiration in the Yangtze River basin. - Theoretical and Applied Climatology 90(1-2): 13-23.

[23] Wu, Y. M., Li, N., Lu, W. D., Xu, Y. P., Chen, X. P. (2006): Long-Term Influence of Urbanization on Runoff in Xitiaoxi River Basin. - Journal of China Hydrology 26(4): 8184.

[24] Xie, Z. H., Su, F. G., Liang, X., Zeng, Q. C., Hao, Z. C., Guo, Y. F. (2003): Applications of a surface runoff model with Horton and Dunne runoff for VIC. - Advances in Atmospheric Sciences 20(2): 165-172.

[25] Xu, C. Y., Gong, L. B., Tong, J., Chen, D. L. (2006b): Decreasing reference evapotranspiration in a warming climate-a case of Changjiang (Yangtze) River catchment during 1970-2000. - Advances in Atmospheric Sciences 23(4): 513-520. 
[26] Xu, C. Y., Gong, L., Jiang, T., Chen, D., Singh, V. P. (2006a): Analysis of spatial distribution and temporal trend of reference evapotranspiration and pan evaporation in Changiiang (Yangtze River) catchment. - Journal of Hydrology 327(1-2): 81-93.

[27] Xu, Y. L., Huang, X. Y., Zhang, Y., Lin, W. T., Lin, E. D. (2005): Statistical Analyses of Climate Change Scenarios over China in the 21st Century. - Advances in Climate Change Research 1(2): 80-83.

[28] Xu, Y. L., Jones, R. (2004): Validating PRECIS with ECMWF Reanalysis Data over China. - Chinese Journal of Agrometeorology 25(1): 5-9.

[29] Zhang, Q., Li, H. P., Xu, L. G. (2006): Surface Runoff Modeling for Xitiaoxi Catchment, Taihu Basin. - Journal of Lake Sciences 18(4): 401-406.

[30] Zhang, Q., Peng, J. T., Xu, C. Y., Singh, V.P. (2014): Spatiotemporal variations of precipitation regimes across Yangtze River Basin, China. - Theoretical Applied Climatology 115: 703-712. 